Aco Lukić ${ }^{1}$

Smiljana Đukičin Vučković

Anđelija Ivkov-Džigurski

Ljubica Ivanović Bibić

Tamara Jovanović

Prirodno-matematički fakultet, Departman za geografiju, turizam i hotelijerstvo, Univerzitet u Novom Sadu
Primljen: 26.08.2020.

Prihvaćen: 23.11.2020.

UDK: $373.333: 91$

DOI $10.19090 /$ ps.2020.2.179-190

\title{
TEHNIKA UPOTREBE DRAME U NASTAVI GEOGRAFIJE
}

\author{
Apstrakt
}

Upotreba drame je aktivan pristup u procesu učenja gde se učesnici identifikuju s ulogom koju igraju, kao i situacijama u kojima se nalaze. Ovakav segment nastave zapravo zalazi i u vanjezičku kategoriju, jer socijalna interakcija uključuje komunikaciju na mnogim nivoima. U užem, konkretnijem smislu, tehnika drame uključuje pantomimu, igranje uloga, improvizaciju, simulaciju, interaktivne aktivnosti kao što su različiti oblici dijaloga i dramatizacija narativnog teksta. Dakle, upotreba tehnike drame u nastavi nije novi koncept. Tehnika drame pruža odličnu osnovu za istraživanje teoretskih i praktičnih aspekata nastave. U ovom radu obrađena je tehnika drame $u$ nastavi geografije, način njenog izvođenja i primena u samoj nastavi. Takođe, prikazana je i kao inovacija u nastavi geografije, tehnika koja na poseban način stavlja učenika u prvi plan u nastavi, odstupa od tradicionalnih nastavnih metoda i uključuje učenika u sam nastavni proces. Eksperimentalno istraživanje sprovedeno je među učenicima drugog razreda gimnazije opšteg smera. Uzorak su činili učenici koji su podeljeni po razredima u eksperimentalnu i kontrolnu grupu, odnosno učenici sa kojima je ista nastavna jedinica odrađena na tradicionalnom tipu časa i učenici koji su nastavnu jednicu obradili tehnikom drame. Istraživanje je pokazalo da su deca prihvatila novu nastavnu tehniku i sa istom savladala datu nastavnu jedinicu. Aktivizacija učenika stavljena je u prvi plan.

Ključne reči: tehnika drame, nastava, geografija, učenik, obrazovanje

\section{Uvod}

Upotreba drame u vaspitanju je dramska aktivnost koja za cilj ima procesno orijentisano iskustvo svojih aktera. Ovakav rad razlikuje se od dramskih časova, u kojima

\footnotetext{
acolukic994@gmail.com
} 
je glavni cilj priprema za nastup. Drama u vaspitanju je improvizacija, a ne egzibicija. Ona je proces koji ima formu drame, u kojoj su njeni učesnici, deca, vođeni od strane nastavnika da zamišljaju, razmišljaju i prikazuju iskustveno stečeno znanje.

Kreativan proces je dinamičan. Nastavnik vodi decu u svet istraživanja u kojem se izražava i komunicira idejama, konceptima, osećanjima. Tehnika drame se povezuje i ima najbolji efekat kod dece između 4 i 9 godina, to jest usmeren je na godine razvoja kada akteri - deca mogu imati najviše koristi od dramskih iskustava samo ako nisu pod pritiskom javnih nastupa. Važna je kreacija, a ne nastup. Drugim rečima, kreativna drama nije obuka i priprema dece za nastup pred publikom. Kreativna drama pridaje podjednaku važnost i verbalnoj i neverbalnoj improvizaciji. Ona priča priču, stvara atmosferu bajke o činjenicama, istražuje, opipava, prezentuje deci stvarni svet na maštovit način. Kreativna drama se obično izvodi u formi dramskih radionica i uključuje: dramske igre, priče, igre uloga, odnose među kreiranim likovima, improvizacije, pantomimu, narativnu pantomimu, kreativne pokrete, dramatizacije, zamišljena putovanja, vođenu fantaziju, muziku, ples. U kreativnoj drami se upotrebljavaju raznovrsne priče i događaji da bi pokrenuli dečiju imaginaciju i originalno kreativno mišljenje (Više u: Bojović, 2010).

Kada dete u okviru aktivnosti zbog straha ili stida želi samo da posmatra ali ne i da učestvuje, nastavnici će poštovati njegovu potrebu. Takođe, u obrnutom slučaju, ako su deca izrazito motivisana za rad, nastavnik može postati samo član grupe, a deci prepustiti da vode aktivnost. Svaki nastavnik može da uspostavi kreativnu dramu kao deo svoga rada, kao jednu od tehnika koju koristi. To je umetnička forma koja podrazumeva kooperativnost i odnose međusobne saradnje učenik-učenik, učenik-nastavnik i nastavnik-učenik. Ona usmerava učenike da, pre svega pozitivno misle o sebi, da veruju u svoje narastajuće sposobnosti i mogućnosti. Često se nastavnici osećaju nesigurno da uvedu dramske tehnike i aktivnosti bez saradnje školovanih dramskih umetnika. Tehnika drame koristi se za dečiji sveobuhvatni razvoj, a kako autor Bojović (2010) navodi najviše za: 1) samopouzdanje i pozitivan samokoncept, 2) imaginaciju, 3) empatiju i toleranciju, 4) jezik i sposobnosti komunikacije, 5) kreativnost u rešavanju problema, 6) pamćenje, 7) estetske vrednosti.

Prednost ovakvog rada je što može biti veoma praktičan i ekonomičan za primenu. Mane su to što se zanemaruju individualne razlike kod učenika, dolazi do opadanja pažnje i aktivnosti na času. Do sada je na času dominantnu ulogu imao nastavnik, a učenici su bili pasivni slušaoci (Turković, 2017).

Po svemu gore navedenom, može se reći da tehnika drame zaista utiče na razvoj dečijeg mišljenja, otvara nove horizonte kod dece za njihovo kreativno izražavanje, a samim tim ih postiče i na pamćenje i lakše savladavanje gradiva. Tehnika drame na samoj završnici procesa podstiče učenike na kritički osvrt odrađenog nastavnog procesa. Nastava geografije daje mogućnosti za primenu ove tehnike zbog specifičnog polja proučavanja. Učenici, kako u osnovnoj, tako i u srednjim školama, nastavne jedinice mogu obrađivati ovom tehnikom. Cilj ovog istraživanja je primena tehnike 
drame pri obradi novih nastavnih jedinica u gimnaziji. Tokom istraživanja, pokazalo se da učenici imaju interesovanja za obradu gradiva ovom tehnikom, jer davanjem glavne uloge na času učenicima podstičemo njihovu aktivnost i stavljamo ih u prvi plan, dajemo im ulogu vođe i mogućnost obrade novog gradiva po njihovim sopstvenim idejama. U istraživanju je korišćen eksperiment koji je sproveden u kontrolnoj i eksperimentalnoj grupi. Cilj je bio da se utvrdi na kom tipu časa su učenici postigli bolje rezultate i da li su prihvatili tehniku drame kao novi način obrade nastavne jedinice. Nastavnik je kontrolisao sam nastavni proces, a učenici su obrađivali nastavnu jedinicu uz datu mogućnost da njihove ideje i kreativnost usmeravaju u pravcu u kom je čas planiran.

\section{Tehnika drame u nastavi}

Dramski izraz podrazumeva svaki oblik izražavanja u kojem su stvarni ili izmišljeni događaji, bića, predmeti, pojave i odnosi predstavljeni pomoću odigranih uloga i situacija. Dramska aktivnost deluje holistički integrišući intelektualnu spoznaju, proživljene emocije i estetski doživljaj u celovito iskustvo koje potkrepljuje i osnažuje svaki dalji korak lične aktivnosti učesnika usmerenog bilo na učenje, na lični razvoj i rast, na javno izražavanje (Krušić, 2014). Bitna karakteristika drame u obrazovanju je da se prvenstveno bavi dramskim procesom, a sekundarno rezultatom: to znači da je više interesuje sam procesni rad nego predstava, jer su njeni ciljevi razvojni pre nego umetnički. Najznačajnija odlika dramskog procesa je to što se dramska struktura konstruiše od strane nastavnika i učenika, kao kreativan rad. Važan deo dramske radionice (kao jedinice u vođenju procesa) je završnica u kojoj se odvijaju zajednička analiza i razgovor o stečenom iskustvu učesnika (Milosavljević, 2014).

Primena drame u obrazovanju izuzetno je korisna za lični razvoj učenika svih uzrasta. Dramski izraz podstiče razvoj mašte, aktivira kreativne sposobnosti i povećava koncentraciju i pažnju. Kod dece se neguje stvaralački odnos kako prema sebi, tako i prema drugima, radu i životu (Džokić, 2010). Deca najbolje uče jedna od drugih i dok njihovi nastavnici uče sa njima (Robinson, 2011). Uvođenje drame u obrazovanje menja nastavni proces tako da ideje o aktivnoj nastavi i aktivnom učenju postaju stvarnost. Učionica menja svoj izgled drugačijim rasporedom nameštaja, jer postoji potreba da svi jasno vide šta se dešava „na sceni” i ne žele da im klupe i mesto sedenja budu zaštita od mogućih „,neprijatnih” nastavničkih pitanja. Učenici su učesnici u procesu, bilo kao publika ili kao neposredni akteri proigravanja sadržaja (Krušić, 2013).

Koristeći se dramskim elementima u nastavnom procesu, ne težimo savršenoj dramskoj interpretaciji već se nizom kratkih dramskih improvizacija cilj usmerava na sticanje određenih znanja i veština i primenu stečenih znanja u realnim uslovima, kao i na razvijanje kritičkog mišljenja, sticanje samopouzdanja i samostalnog prilaza raznim problemskim situacijama (Čubrilo, 2008). 
Bojović (2010) navodi da sama dramska aktivnost predstavlja proživljeno iskustvo i da za posmatrača može biti nezanimljivo i manjeg inteziteta u odnosu na neposrednog igrača za koga $\mathrm{u}$ istom momentu može biti uzbudljivo kao i prepuno emocija i zadovoljstva.

\section{Nastava i mogućnost korišćenja tehnike drame u nastavi geografije}

Poznato je da nastavu čine poučavanje i učenje, odnosno aktivnosti nastavnika i učenika. Očigledno je da su ovi procesi tesno povezani i međusobno uslovljeni. Nastava uvek predstavlja učenje i u funkciji je učenja, ona i postoji zbog učenja. Sa druge strane, aktivnost nastavnika se ne može zamisliti bez odgovarajućih aktivnosti učenika ne samo kada se radi o usvajanju znanja već i znatno šire. Očekuje se intenzivno angažovanje i stvaralački odnos učenika prema onome što se saznaje. Zbog toga učenje zaslužuje posebnu pažnju kada se razmatra nastava i nastavni proces (Poljak, 1980).

Savremeno doba, savremeni pristupi nastavi pa onda i kurikulumi otvaraju vrata nekim novim, drugačijim i jednako uspešnim načinima koji uzimaju u obzir učenička iskustva i njihove interese (Rimac Jurinović, 2018).

Tehnika drame podstiče vođstvo, timski rad, kompromis, veštine slušanja. Nova atmosfera je prilika da se prezentovani sadržaji prožive i dožive, da se kao takvi lako uklope u postojeća saznanja i na taj način postanu trajna svojina onih koji uče. Nastavnik koji ovo organizuje dobija ideal nastave - zainteresovanost, partnerstvo, dobru razmenu, trajna znanja primljena kognitivno, emocionalno i bihevioralno. Drama se najčešće koristi u nastavi srpskog jezika i književnosti, kao i stranih jezika, ali ima veliku mogućnosti primene i u svim društvenim naukama, samim tim i u nastavi geografije (Balić i Dragović, 2013).

Da bi dramsko vaspitanje bilo efikasno, nužno je decu osloboditi straha od greške, uveriti ih da svako ima pravo na grešku jer je greška način učenja. To je moguće postići jedino ako osete da nisu kontrolisana i procenjivana. Ocenjivanje nije u skladu s osnovnim načelima dramskog vaspitanja. Takođe je važno osvestiti učenike da su svi u igri ravnopravni i jednako važni i da nijedna situacija bez nekoga od njih ne bi bila jednaka, da je svaki pojedinac čini neponovljivom i jedinstvenom. Nakon što deca prihvate ova dva jednostavna pravila, prihvatiće i da u dramskim igrama ne postoji "neću", "ne znam" i "ne mogu", čak i ako im se neki zadatak čini teškim. Pre početka rada potrebno je jasno postaviti pravila igre i njen cilj i svrhu, moraju biti razjašnjene nejasnoće kako se igra ne bi morala prekidati. Sva ova pravila važe i za nastavnika. Nastavnik sme u igri učestvovati kao igrač ili kao neutralni posmatrač što znači da ni u kom slučaju ne sme nepotrebno prekidati igru i upozoravati igrače na greške, komentarisati ili objašnjavati učinjeno, odigrano (Lekić, 2007). 


\section{Metodologija istraživanja}

Na oglednim časovima koji su realizovani, težište je stavljeno na tehniku drame u nastavi. Časovi su održani na dva načina, kroz aktivnu i kroz tradicionalnu nastavu. Tradicionalna nastava realizovana je frontalnim oblikom rada, u dva odeljenja (54 učenika), a aktivna tehnikom drame, u druga dva (53 učenika). Ogledni časovi su održani u četiri odeljenja drugog razreda Gimnazije "Svetozar Marković" u Novom Sadu, školske 2018/19. godine. Nastavna jedinica koja je obrađena tokom četiri časa je "Prirodne odlike Evrope". Frontalni oblik rada je najzastupljeniji i osnovni oblik rada koji se koristi u nastavi. Predstavlja istovremeno podučavanje celog odeljenja, istovremeni nastavnikov rad sa celim razredom. Ovakvim oblikom rada, učenici jednog odeljenja rade iste poslove pod neposrednim nastavnikovim rukovodstvom, pri čemu se od svakog učenika mogu postavljati podjednaki zahtevi (Romelić, 2004).

Na kraju održanih časova, učenicima je dat test koji se sastojao iz tri dela. Prvi deo testa činilo je deset kratkih pitanja gde su učenici kratko odgovarali, dopunjavali ili povezivali date pojmove. Drugi deo testa bila je nema karta, dok je za ispitivanje trećeg dela korišćena Likertova skala stavova koja se sastojala iz 5 tvrdnji posvećenih različitim aspektima stavova o održanom času. Likertova skala se daje ispitaniku sa zadatkom da za svaku pojedinu tvrdnju izrazi stepen svog slaganja ili neslaganja, po pravilu, na petostepenoj skali (1 - u potpunosti se ne slažem, 2 - ne slažem se, 3 nemam mišljenje, 4 - slažem se, 5 - u potpunosti se slažem). Svaki odgovor ispitanika se boduje na odgovarajući način, a onda se sabiranjem bodova i izračunavanjem srednje vrednosti za svaku tvrdnju dobija ukupni rezultat koji izražava stav ispitanika (Likert, 1932). U druga Prvi i drugi deo testa radila je kontrolna grupa koja je časove realizovala na tradicionalan način. Eksperimentalna grupa koja je nastavne sadržaje realizovala tehnikom drame, radila je i treći deo testa. Dobijeni podaci analizirani su u statističkom programu SPSS (Statistical Package for the Social Sciences). Statističke analize koje su najčešće i koje su primenjene u ovom istraživanju su: inicijalna deskriptivna statistička analiza i T-test analiza. T-test za nezavisne uzorke se koristi za upoređivanje srednje vrednosti rezultata i za utvrđivanje statističke značajnosti njihovih razlika (Pallant, 2007). Hipoteza na kojoj se zasniva rad i koja je postavljena pre samog istraživanja glasi da učenici postižu bolje rezultate primenom tehnike drame i kroz samu aktivnu nastavu. Podhipoteza rada se zasniva na tvrdnji da postoji statistički značajna razlika između potignuća učenika u aktivnoj i tradicionalnoj nastavi.

U kontrolnoj grupi korišćena je uglavnom metoda upotrebe monologa, uz kombinaciju sa metodama upotrebe dijaloga i ilustracije i demonstracije. Na uvodnom delu časa, koji je trajao 5-10 minuta, korišćena je metoda upotrebe dijaloga kako bi se dobila povratna informacija o tome koju su nastavnu jedinicu učenici prethodno obradili i koliko su zapamtili. Nizom nastavnikovih pitanja učenici su došli sami do zaključka koju nastavnu jedinicu će obraditi taj čas. Glavni deo časa trajao je 25 minuta. Učenicima su iznete glavne karakteristike privrede Evrope, sami su dolazili do zaključaka, koji 
oblici reljefa su zastupljeni, koja klima u kojim delovima Evrope i kako sve to utiče na broj i raspored stanovništva i drugih društveno-geografskih pokazatelja. Nakon što su učenici zapisali u sveske najvažnije informacije iz obrađene lekcije, izvršeno je ponavljanje. U završnom delu časa (10 minuta) učenici su imali vremena da urade test iz nastavne jedinice koja je obrađena taj čas i koji će nastavniku služiti da utvrdi učenička postignuća.

U eksperimentalnoj grupi korišćena je kombinacija frontalnog (na uvodom i na početku glavnog dela časa) i grupnog oblika rada (tehnika drame). U uvodnom delu časa ponovljeni su ranije usvojeni elementi koji su bili neophodni za prelazak na novu nastavnu jedinicu. Učenici su kroz pitanja od strane nastavnika sami došli do zaključka koja nastavna jedinica će se obraditi taj čas. Frontalni oblik rada primenjen je prvih 5-7 minuta glavnog dela časa, kako bi se učenici upoznali sa nastavnom jedinicom i tom prilikom je korišćena monološka metoda. Učenici su upućeni u dalji način rada. U narednih 25-30 minuta učenici su bili podeljeni u tri grupe. Prva grupa obrađivala je Položaj i reljef Evrope, druga grupa Klimu Evrope, a treća grupa Kolonizaciju, stanovništvo i religije. Zadatak za učenike je bio da ostalim učenicima iz odeljenja predstave najvažnije karakteristike svog dela gradiva, koristeći tehniku drame. Učenicima su podeljene nalepnice i smernice u kojima je bilo objašnjeno na koji način da odrade svoj deo gradiva. Učenici prve grupe imali su zadatak da predstave Evropu kroz kratki monolog, i objasne geografski položaj našeg kontinenta. Takođe, imali su zadatak da predstave nizije, planine i kažu njihove glavne karakteristike u Evropi, uz pokazivanje na karti. Druga grupa je mimikom i pantomimom objasnila gde je koja klima zastupljena i koje su njene osnovne karakteristike. Treća grupa je glumom odradila svoj deo gradiva (Kolumbova putovanja, otkriće novog sveta i kolonizaciju istog), zatim su pomoću karte predstavili gde živi najviše ljudi u Evropi i gde je koja religija zastupljena. Dok je jedan učenik držao monolog ostali su pokazivali na karti, dva učenika su deo o religijama odglumili. U završnom delu časa ponovljeno je najvažnije gradivo, nakon čega je usledilo testiranje.

\section{Rezultati i diskusija}

Kako je već napomenuto, nakon realizacije časova kontrolne i eksperimentalne grupe, bilo je testirano ukupno 107 učenika drugog razreda gimnazije. U nastavku će biti prikazana uporedna analiza postignutog uspeha na testovima obe grupe. Maksimalan broj bodova koji su učenici mogli da ostvare je 100, a kriterijum ocenjivanja bio je sledeći:

- 0-30 bodova, ocena 1 ,

- 31-50 bodova, ocena 2,

- 51-70 bodova, ocena 3,

- 71-90 bodova, ocena 4,

- 91-100 bodova, ocena 5. 
Tabela 1

Postignut uspeh na testu

\begin{tabular}{ccc}
\hline Ocena & $\begin{array}{c}\text { Kontrolna grupa } \\
\text { Tradicionalan tip časa }\end{array}$ & $\begin{array}{c}\text { Eksperimentalna grupa } \\
\text { Aktivan tip časa }- \text { tehnika } \\
\text { drame }\end{array}$ \\
\hline 1 & 0 & 0 \\
2 & 1 & 0 \\
3 & 6 & 4 \\
4 & 14 & 8 \\
5 & 33 & 41 \\
Ukupno & 54 & 53 \\
Prosek & 4,46 & 4,69 \\
\hline
\end{tabular}

Uvidom u Tabelu 1. može se zaključiti da je konačan prosek učenika na testu veći na času održanom sa korišćenjem tehnike drame nego na tradicionalnom tipu časa. Međutim, prosek se razlikuje samo za 0,23. Kada se uporede same ocene vidi se da je mnogo više odličnih učenika, kao i manje učenika sa ocenama vrlo dobar i dobar u odeljenjima u kojima je rađen čas tehnikom drame. Rezultati testa koji su pokazali bolja postignuća učenika primenom tehnike drame, potvrdili su podhipotezu rada. Pozitivni komentari učenika posle časa takođe to potvrđuju. Učenici su komentarisali da im je čas bio jako zanimljiv jer je sve odrađeno kroz igru i glumu i da su mnogo naučili na ovom času.

Aktivna nastava prati modernizaciju nastave, uključuje učenike u rad i povećava njihovu zainteresovanost u nastavi, jer oni sami, kroz grupni oblik rada koji je ovde korišćen, učestvuju pred svojim odeljenjem u nastavi i dobijaju ulogu nastavnika. Ovde se može javiti problem da su učenici okupirani svojim zadatkom i žele što bolje da nauče svoj deo koji treba da izlože i zbog toga dolazi do smanjenja pažnje kod učenika tokom izlaganja drugih. Smanjenjem pažnje propuštaju se delovi nastavne jedinice i zbog toga može doći do smanjenja usvojenog znanja. Iz tog razloga, potrebno je svima dati isto vremena da pripreme svoj deo, oko 10 minuta, i nakon toga zadatak nastavnika je da prati da li svaki učenik u razredu prati nastavnu jedinicu. U prilog povećanoj pažnji učenika ide i činjenica da im je gluma drugih zanimljiva i motivišuća.

$\mathrm{Na}$ tradicionalno održanom času su učenici pažljivo slušali nastavnika i zajedno sa njim dolazili do rešenja. Nastavnik je kod učenika formirao predstavu i pojam o određenim karakteristikama date nastavne jedinice, ali treba uzeti u obzir da sama monološka metoda postaje monotona učenicima kao i sam frontalni oblik rada. U ovom obliku rada učenike je potrebno maksimalno uključiti u sam nastavni proces. NemethJajić (2008) smatra da dramske igre u nastavi slede isti obrazac koji je sačinjen od toga da se učenici uživljavaju u dodeljene uloge, a tema razgovora je dogovorena u odnosu 
na nastavni sadržaj. Takođe, navodi da ne treba zanemariti ni ulogu humora koji se u takvim igrama razvija. Elementi humora su izraženiji, što je pojam koji treba oživeti apstraktniji.

Dramska pedagogija mogla bi biti odgovor na većinu ranije postavljenih zahteva. Dramski izraz izuzetno koristan za razvoj učeničke ličnosti. Takođe, dete dramskom igrom, odnosno tehnikom drame isprobava razne situacije u kojima će se možda kasnije naći, te mu se omogućava da igranjem različitih konfliktnih situacija i kontaktom s različitim karakterima „bezbolno istraži kako je to biti odrastao“, odnosno uči o životu (Gruić 1999, Rimac Jurinović, 2018). Dramska radionica može da zadovolji zahteve savremene organizacije nastave, navode Lazarević i sar. (1993), jer aktivira učenika na način da se stvaraju uslovi za postizanje obrazovno-vaspitnih ciljeva koji se postavljaju u samoj nastavi, a posebno ciljeva u afektivnom domenu nastave.

Da bi učenici usvojili osnove geografije potrebno je da savladaju sistem fundamentalnih pojmova i kategorija. Percepcija (opažanje) je čovekovo organizovanje i interpretacija senzacija. Pravo geografsko posmatranje predstavlja plansko percipiranje. Nastavnici treba da usmeravaju učenika ka planskom percipiranju (opažanju). Ono će biti plansko ako ih nastavnik uputi kako treba da ga organizuju i na koja ranija znanja $i$ iskustva treba učenici da se pozivaju. Opšti pojmovi sadrže opšte zajedničke bitne crte geografskih pojava iste vrste, i izražavaju suštinske odlike stvari. Pojmovi koji predstavljaju pojave nematerijalne prirode označeni su kao apstraktni geografski pojmovi (Romelić, Ivanović, 2015).

Tabela 2

Evaulacija časa

\begin{tabular}{lcccc}
\hline \multicolumn{1}{c}{ Tvrdnje } & N & Minimum & Maximum & $\begin{array}{c}\text { Srednja } \\
\text { vrednost }\end{array}$ \\
Čas mi je bio zanimljiv & 53 & 3 & 5 & 4.83 \\
$\begin{array}{l}\text { Metod rada je interesantan } \\
\text { Način rada nastavnika i ove metode }\end{array}$ & 53 & 3 & 5 & 4.74 \\
mi odgovara & 53 & 3 & 5 & 4.75 \\
$\begin{array}{l}\text { Sadržaj časa i ove metode mi } \\
\text { odgovara }\end{array}$ & 53 & 1 & 3 & 1.25 \\
$\begin{array}{l}\text { Osećao sam se zapostavljeno na } \\
\text { času }\end{array}$ & 53 & 3 & 5 & 4.60 \\
$\begin{array}{l}\text { Naučio sam današnju lekciju } \\
\text { Ukupno }\end{array}$ & 53 & & & 5 \\
\hline
\end{tabular}

Uvidom u Tabelu 2 u kojoj su analizirani odgovori učenika došlo se do zaključka da najveću srednju vrednost ima prva tvrdnja "Čas mi je bio zanimljiv". Sledeća sa 
najvišom prosečnom ocenom jeste tvrdnja "Način rada nastavnika i ove metode mi odgovara", kao i "Metod rada je interesantan". Ove tvrdnje prate i sve ostale, što ukazuje da su učenici pozitivno ocenili tehniku drame u nastavi, jer su i sami učestvovali u obradi nove nastavne jedinice. Sve tvrdnje koje su u vezi sa datom tehnikom su iznad 4,50 što ukazuje na odlične rezultate rada nastavnika i date tehnike. $U$ anketi se našla i tvrdnja "Osećao sam se zapostavljeno na času" koja je očekivano dobila najnižu ocenu jer su svi učenici bili uključeni u nastavni proces. Tvrdnja ne prelazi graničnu vrednost od $1,50(1,25)$ što govori da je svega 9 od 53 učenika ocenilo ovu tvrdnju sa više od 1 i to njih 5 sa 2, a ostali (4) sa 3 na Likertovoj skali. Data analiza govori da su učenici odlično prihvatili primenu drame u nastavi i sa datom tehnikom savladali nastavni sadržaj. Učenici koji su slabije ocenili celokupan proces možda su bili nezadovoljni načinom rada, da li zbog dodeljene uloge ili neadekvatne grupe u kojoj su trebali da rade i slično.

Nakon realizacije pedagoškog eksperimenta izvršeno je finalno testiranje. Ponovnim uvidom u tabelu 1 vidi se da su učenici na aktivnom času dobili veću prosečnu ocenu. Dobijeni rezultati t-testa ukazuju da postoji statistički značajna na nivou značajnosti $\mathrm{p}<0.01$ po pitanju stečenih znanja iz navedenih geografskih sadržaja između učenika eksperimentalne i kontrolne grupe. Dobijeni rezultati upućuju na zaključak da primena tehnike drame u realizaciji napred navedenih sadržaja geografije kod učenika srednje škole pozitivno utiče sticanje znanja. Ovim je potvrđena glavna hipoteza rada koja glasi da učenici postižu bolje rezultate primenom tehnike drame i kroz samu aktivnu nastavu. Nastava uz primenu tehnike drame obezbeđuje dobru osnovu za aktiviranje i učenika sa slabim uspehom jer im pomaže da nauče i zapamte osnovne pojmove dovoljne za zadovoljenje osnovnog nivoa znanja potrebnog za dobijanje pozitivne ocene. Takođe, ovakav model nastave može biti podsticaj učenicima da se angažuju za postizanje viših nivoa znanja. Iznetom evaluacijom časa uočava se da su odgovori ispitanika, u ovom slučaju učenika, u saglasnosti sa svim gore pomenutim. Obradom i analiziom rezultata dobijenih testiranjem učenika nakon obrade nastavne jedinice potvrđena je i podhipoteza rada koja se zasniva na tvrdnji da postoji statistički značajna razlika između potignuća učenika u aktivnoj i tradicionalnoj nastavi.

\section{Zaključak}

Uloga umetnosti nije samo da pokaže kakav je svet, nego i da objasni zašto je takav i kako bi se mogao promeniti. Tokom rasta i razvoja mladih ljudi ključni je pojam empatije, koji bi trebalo da usvajaju od najranijeg detinjstva, a dramska aktivnost u tome, svakako, može mnogo da pomogne. Tehniku drame moguće je uključiti u prošireno poimanje dramskog fenomena samo ako se ova tehnika shvati kao opšteljudska sposobnost, antropološka osobina svojstvena svim ljudima, koja se ispoljava u ostvarenjima ove vrste umetnosti, odnosno, u ovom slučaju tehnike drame. 
Kod dece se uz stremljenje ka podražavanju javlja i sposobnost uživljavanja. Zahvaljući toj sposobnosti, dete se brzo i spontano poistoveti sa svim licima, životinjama ili stvarima koje ga svojom sudbinom ili nekim svojstvom privlače ili uzbuđuju, izazivaju ili oduševljavaju. Dramske igre, kao oblik nastave, razvijaju disciplinovanje dečijeg tela i duha, ali je važno da deca na ovu disciplinu igre pristaju. To omogućava uvođenje i kasnije nametnute ili zadate discipline koja iziskuje još potpunije ovladavanje svojim telom i duhom, a u tom procesu, veliku ulogu imaju upravo igre. Prema tome, najvažniji ciljevi ove tehnike su da omogućavaju učenicima kritičko upoznavanje sebe i sveta oko sebe razvijajući njihova pozitivna stremljenja i sposobnosti kao vrednost cele društvene zajednice. Raznim igrama koje uključuju podražavanja ili imitaciju, dete se približava umetnosti. Treba još napomenuti da prikazujući neki svoj doživljaj pomoću dramske ili dramatizovane igre kod deteta nema za cilj da prikaže njegove glumačke sposobnosti, niti da time stvara svoje pozorište sve dok i to ne počne podražavati. Gotovo svi nastavni sadržaji pogodni su za igranje dramskih igara, ali sve opet zavisi od inovativnosti i kreativnosti samih izvođača nastavnog procesa. Ukoliko se želi savremenost škola u kojima se deca poučavaju inovativnim metodama, onda se treba potruditi i uvesti tehnike drame u praksu.

Nastava geografije daje odlične mogućnosti za izvođenje časa tehnikom drame. Regionalna geografija daje učenicima mogućnost da različite narode, njihove kulture, način privređivanja i odnose ka ostatku sveta, predstave na času tehnikom drame. Sama geografija kao nastavni predmet je bogata informacijama, pre svega različitošću prostora i bogatstvom narodnih grupacija, što učenicima daje mogućnost da osmisle i predstave različite nastavne teme na način kako ih oni vide, i s toga lakše usvoje nastavno gradivo. Ono što je sigurno je to da za organizovanje aktivne nastave koja će učenicima pomoći da lakše savladaju gradivo nije potrebno često korišćenje savremenih nastavnih tehnologija, već samo malo truda, i kreativnosti predmetnog nastavnika. Svakako da su danas, zahvaljujući brzom razvoju tehnologije i svemu što ona pruža, mogućnosti mnogo veće. Nastava ne treba da se zadržava na tradicionalnom pristupu, već treba da ide u korak sa vremenom. 
Aco Lukić Smiljana Đukičin Vučković

Anđelija Ivkov-Džigurski

Ljubica Ivanović Bibić

Tamara Jovanović

Faculty of Sciences, Department of Geography, Tourism and Hotel Management, University of Novi Sad

\title{
DRAMA TECHNIQUE USE IN GEOGRAPHY TEACHING
}

\begin{abstract}
Using drama is an active approach in the learning process, where participants identify with the role they play, as well as the situations in which they find themselves. This segment of teaching actually falls into the non-linguistic category, because social interaction includes communication on many levels. In a narrower, more concrete sense, drama techniques include pantomime, role-playing, improvisation, simulation, interactive activities such as various forms of dialogue, and dramatization of narrative text. Thus, the use of drama technique in teaching is not a new concept. The drama technique provides an excellent basis for exploring the theoretical and practical aspects of teaching. This paper discusses the technique of drama in teaching geography, the way it is performed and applied in teaching geography. Also, the technique of drama was presented as an innovation in teaching geography, a technique that in a special way puts students in the foreground in teaching, deviates from traditional teaching methods and involves students in the teaching process itself. The experimental research was conducted among the students of the second grade of the general high school. The sample consists of students who are divided by classes into experimental and control groups, ie students with whom the same teaching unit was done on the traditional type of class and students who did the teaching unit with the drama technique. The research showed that the children accepted the new teaching technique and with it they mastered the given teaching unit. The activation of students was put in the foreground.
\end{abstract}

Keywords: drama technique, teaching, geography, student, education

\section{Literatura}

Balić, D., Dragović, S. (2013). Drama Pedagogy: A Way of Learning through Experience and by Doing. Croatian Journal of Education, 15 (1/2013), 191-209.

Bojović, D. (2010). Više od igre: Ispričaj mi priču. Dramske metode u radu s djecom. Split: Harfa d.o.o. 
Čubrilo, V. (2008). Dramska skupina u osnovnoj školi 2, 267-61, Zagreb: Hrvatski časopis za teoriju i praksu nastave.

Džokić, Z. (2010). Moć psihodrame. Psihopolis institut. Novi Sad

Gruić, Iva. (1999). Odgojno kazalište. Zbornik Učiteljske akademije u Zagrebu 1. 219223.

Krušić V. (2014). Okvir za različitost - Razvoj suvremene dramske pedagogije 2, 5661, Novi Sad: „Scena” - časopis za pozorišnu umetnost.

Krušić, V. (2013). Što sve može drama. Zagreb: HCDO.

Lazarević, D. A., Sinđelić, M., \& Vlahović, E. (1993). The drama workshop in the psychological education at secondary schools. Psihologija, 26(1-2), 173-180.

Lekić, K. (2007). Igram se a učim. Zagreb: HCDO.

Likert, R. (1932). A technique for the measurement of attitudes. In: Archives of Psychology, R.S. Woodeorth (Ed.), No. 140, New York University, New York.

Milosavljević, S. (2014). Drama u obrazovanju dece i mladih - Iskustva i refleksije 2, 40-47, Novi Sad: „Scena” - časopis za pozorišnu umetnost.

Nemeth-Jajić, J. (2008). Igrokaz u razrednoj nastavi. Hrvatski: časopis za teoriju i praksu nastave hrvatskoga jezika, književnosti, govornoga i pismenoga izražavanja te medijske kulture, 6(1),29-44.

Pallant, J. (2007). SPSS Survival Manual A step by step guide to data analysis using SPSS for Windows version 15. (3rd Ed.). Crows Nest, N.S.W.: Allen \& Unwin.

Poljak, V. (1980). Didaktika. Drugo izdanje. Zagreb: Školska knjiga.

Rimac Jurinović, M. (2018). Procesna drama u kurikulumu suvremene škole (doktorska disertacija). Zagreb: Odsjek za kroatistiku Filozofskog fakulteta.

Robinson K. (2011). Element, otkrijte svoje talente - budite kreativni - radite ono što volite. Zagreb: HCDO.

Romelić, J. (2004). Metodika nastave geografije. Prirodno-matematički fakultet. Departman za geografiju truisam i hotelijerstvo. Novi Sad.

Romelić, J., Ivanović Bibić, Lj. (2015). Metodika nastave geografije. Prirodnomatematički fakultet. Departman za geografiju turizam i hotelijerstvo. Novi Sad.

Turković, J. (2017). Nastavna načela u klasičnoj i aktivnoj geografiji u VI razredu. Master rad. Prirodno-matematički fakultet, Novi Sad. 